\title{
Don Yllán and the Egyptian Sorcerer: Vernacular commonality and literary diversity in medieval Castile
}

\author{
David A. WACKS ${ }^{*}$ \\ University of Oregon
}

The tale of Don Yllán ${ }^{1}$ has been touted by critics as one of the finest examples of Don Juan Manuel's literary artistry. It is responsible, in part, for his reputation as a gifted storyteller. Perhaps not coincidentally, source criticism of the Conde Lucanor $(=C L)$ has not been able to find a single source in Latin, Romance, or Arabic literature with the same combination of narrative motifs employed by Don Juan Manuel in his tale of the Toledan necromancer. In fact, the tale of Don Yllán has a prior Hebrew analogue in the Mešal Haqadmon $\bar{\imath}$

\footnotetext{
*wacks@uoregon.edu

1 Exemplum no. 11 of the Conde Lucanor, or Libro de Patronio. The author, Don
} Juan Manuel (1282-1348) was one of the most powerful Castilian noblemen of his time. His other works include chronicles, treatises on chivalry, politics, hunting, military science, and poetry in praise of the Virgin Mary. For a brief overview of his life and works, see the introduction to the edition of Ayerbe-Chaux: Don Juan Manuel, Libro del Conde Lucanor, ed. Reinaldo AYERBE-CHAUX (Madrid 1983) pp. 310. The definitive biography is Andrés GiménEz SOlER, Don Juan Manuel. Biografía y estudio crítico (Zaragoza 1932). See also David FlORY, El Conde Lucanor: Don Juan Manuel en su contexto histórico (Madrid 1995). For a reliable edition of his complete works, see Juan Manuel, Obras completas, ed. José Manuel BLECUA, 2 vols. (Madrid 1982).

Sefarad 65 (2005) págs. 413-433

(1) CSIC

ISSN 037-0894 
('Tales of the Ancient One' $=M Q$,) of Isaac ibn Sahula (ca. 1285). ${ }^{2}$ The existence of his tale of the Egyptian sorcerer puts the Don Yllán tale in a new light: it tables anew the question of Don Juan Manuel's putative source, and calls into question the extent and nature of his literary innovation. In this essay we examine both tales in terms of their structure, literary style, and didactic orientation. We conclude that the source for both tales is a folktale that circulated orally in Castile during the $13^{\text {th }}$ and $14^{\text {th }}$ centuries. That is, the two tales are cultural first cousins with a common oral grandparent, distinct literary versions written in two different languages. This relationship between the two tales is characteristic of the diverse cultural life of medieval Castile, in which a vernacular culture shared by Jews and Christians nurtured two intertwining strands of literary activity in Hebrew and Castilian.

The story of Don Yllán and the Deán de Santiago is one of the best-known, most frequently anthologized and university classfriendly tales in Don Juan Manuel's work. ${ }^{3}$ Critics and literary historians consider the tale as one of the best examples of Juan Manuel's literary creation, particularly in the choice of Toledo as backdrop for the story of the sorcerer and his ungrateful would-be disciple. On the basis of this tale, Menéndez Pelayo names Juan Manuel as the originator of Spanish novelistic fiction. ${ }^{4}$ Valbuena Prat considers it the most perfect tale in the collection. ${ }^{5}$ More recent critics' praise is

2 Isaac ben Solomon ibn Sahula (b. 1244) was poet, scholar and kabbalist who may have lived in Guadalajara. See Abraham Meir HABERMANN, «Sahula, Isaac ben Solomon abi», in Encyclopedia Judaica CD-ROM Edition, v. 1.0 (=EJ), ed. Geoffrey WigODER (Jerusalem 1997). For further biographical information, see Loewe's introduction to his English translation of $M Q$ : Isaac ben Solomon Ibn Sahula, Meshal Haqadmoni: Fables from the Distant Past, ed. and trans. Raphael LOEWE (Portland 2004) pp. xvi-xxi.

3 See Juan Manuel, Obras 1, p. lx. All citations of texts by Don Juan Manuel are from Blecua's edition.

4 Marcelino Menéndez Pelayo, Orígenes de la novela, vol. 1 (Buenos Aires 1946) p. 157.

5 «Quizá [es] el relato más perfecto de todo el libro (...) La habilidad de todo el cuento, su fina ironía y su enseñanza ejemplar se realizan perfectamente.» Ángel VAlbuena PRAT, Historia de la literatura española, vol. 1 (Barcelona 1937) p. 171. 
only somewhat more reserved: Lida de Malkiel refers to it as «la joya de la colección» ${ }^{6}$ and underscores Juan Manuel's well thought-out structure, the carefully constructed setting, and the artful presentation of the characters. ${ }^{7}$ Galbis praises the tale's superior descriptive, psychological, and stylistic features. ${ }^{8}$ For Serés, the Don Yllán tale is the finest example of Don Juan Manuel's 'mastery'. ${ }^{9}$ AyerbeChaux regards it as the most famous. ${ }^{10}$ John Keller credits him with introducing modern narrativity to Castilian literature. ${ }^{11}$ In all, exemplum no. 11 has received a great deal of praise for its narrative innovation, in terms of both content and style.

The tale scarcely needs retelling: the Deán of Santiago visits Don Yllán of Toledo in order to learn the magic arts from him. ${ }^{12}$ The sorcerer agrees to the mentor-student relationship -with the proviso that when the Deán is next promoted he will recommend Don Yllán's own son to replace the Deán's vacant position. Once the Deán agrees to these terms, Don Yllán leads him down a staircase to a subterranean study, where he begins to instruct the Deán in the magic arts. The higher the Deán ascends in the Church hierarchy, the more disdainful he becomes of the promise made to Don Yllán. In the end,

6 María Rosa Lida DE MALKIEL, «Tres notas sobre don Juan Manuel», Romance Philology 4 (1950) pp. 155-194: p. 158.

7 LIDA DE MALKIEL, «Tres notas», p. 168.

8 Ignacio GaLBIS, «Gérmenes novelísticos en los cuentos de Don Juan Manuel», Explicación de Textos Literarios 7 (1978) pp. 5-12: p. 6-8.

9 «La (...) maestría del autor se aprecia especialmente en la disposición de la historia de don Illán.» Don Juan Manuel, El Conde Lucanor, ed. Guillermo SERÉs (Barcelona 1994) p. 53.

10 «No hay duda de que es el cuento más famoso de la colección.» Reinaldo Ayerbe-ChAuX, El Conde Lucanor: Materia tradicional y originalidad creadora (Madrid 1975) p. 98.

"Keller writes that Juan Manuel's «exemplos are short stories as we know this form of brief narrative today.» John E. KELLER, «A Re-examination of Don Juan Manuel's Narrative Techniques: 'La mujer brava'», Hispania 58 (1975) pp. 45-51: p. 45.

12 For an historical study of the tradition of magic in Toledo, see Francisco MIRANDA, «Vn dean de Sanctiago y don Yllán, el maestro de Toledo: Nigromancia e historia en El Conde Lucanor», Revista Canadiense de Estudios Hispánicos 23 (1999) pp. 329-340. 
he finds himself where he began, in Don Yllán's study in Toledo where he realizes that his ascent to Pope was only an illusion crafted by the sorcerer in order to put his promise to the test. This tale inspired various later literary creations, including Juan Ruiz de Alarcón's 1634 play, La prueba de las promesas, two eighteenth- and nineteenth-century versions found in collections of French legends and folktales, and modern Spanish versions by Azorín and Borges. ${ }^{13}$

Juan Manuel's tale has precedent in several $12^{\text {th }}$ - and $13^{\text {th }}$ - century Latin exempla dealing with the motifs of illusory time, tests of gratitude, and a man made to believe himself king. ${ }^{14}$ However, none of these Latin versions combines the motifs of illusory time (D. 2011 and 2012), the test of gratitude (H.1565), and the man enchanted so as to believe he is king, emperor, or pope (D. 2031.5), as do Don Juan Manuel and Ibn Sahula. ${ }^{15}$ All of them are rudimentary in their novelization and not one approaches the detail and narrative sophistication of the Hebrew and Castilian versions. Such was not the aim of the compilers. Rather, the exempla are meant to provide a structure for extemporaneous versions performed in sermons of Franciscan and Dominican friars. ${ }^{16}$ Modern critics' praise for Juan Manuel's artistry

13 For a complete overview of the «rica descendencia» of the Don Yllán story, see Daniel DEvoto, Introducción al estudio de don Juan Manuel y en particular de El Conde Lucanor: Una bibliografia (Paris 1972) pp. 384-389.

14 Etienne de Bourbon, Anecdotes Historiques, Légendes et Apolologues tirés du recueil inédit d'Etienne de Bourbon, dominicain du xiiie siècle, ed. A. LECOY DE LA MARCHE (Paris 1877) p. 359, § 412; Vincent of Beauvais, Speculum historiale, vol. 3 (Graz 1964-65) p. 1261; Jean Gobi, La Scala Coeli, ed. Marie-Anne POLO DE BEAUlieu (Paris 1991) p. 193, no. 72; La Tabula exemplorum secundum ordinem alphabeti, ed. J. T. WELTER (Paris 1926) p. 22, no. 68; John of Bromyard, Summa praedicantium (Venice 1586) Divitiae, 11, art. 6, 19. For Spanish translations of these Latin sources featuring relevant motifs, see AYERBE-CHAUX, Materia, pp. 239-243.

15 Devoto, Introducción, pp. 382-384; A yerbe-Chaux, Materia, p. 99.

16 «The exemplum was a story which had no independent value, and (...) was usually given in a very concise form to be expanded at the preacher's will.» Thomas CRANE, The Exempla of Jacques de Vitry (London 1890) p. Ixxx. On the exemplum as performance, see Guido BALDASSARI, «Introduzione», in Racconti esemplari di predicatori del due e trecento, eds. Giorgio VARANINI and Guido BALDASSARI, vol. 1 (Rome 1993) pp. xiii-lx: pp. xxii and xxxiv-xxxv. For general studies, refer to 
in the tale is based -to a considerable degree- on his creative combination and elaboration of these motifs present in these exempla. ${ }^{17}$ Although an Arabic source has been suggested by more than one critic, none makes specific comparisons to the Don Yllán tale. ${ }^{18}$ Lida de Malkiel argues that an Arabic source is unlikely, because all other of Don Juan Manuel's exempla absent in Latin or Romance sources maintain their Arabized setting. ${ }^{19}$ Her view is corroborated by the conspicuous absence of any analogue to the Don Yllán tale in traditional Arabic narrative. ${ }^{20}$

Claude Bremond, Jacques Le GofF and Jean Claude SChMitT, L' 'Exemplum» (Turnhout, Belgium 1982).

17 «El tiempo mágico está ya en germen en la Tabula Exemplorum y en el Scala coeli, pero se requería el genio de un escritor como don Juan Manuel para darle dimensión artística y desarrollarlo con una seguridad creadora que es de admirar en un autor medieval.» AYERBE-CHAUX, Materia, p. 102.

18 Several critics parrot Menéndez Pelayo's assertion that the tale has a source in the Arabic Forty Days and Forty nights, among which Angel González Palencia, who reports a «versión bellísima» in J. J. MARCEL, Contes du Cheykh el-Mohdy, 3 vols. (Paris 1835) vol. 3, pp. 18-307. Lida de Malkiel asserts that the version bears little likeness to the Don Yllán tale: LIDA DE MALKIEL, «Tres notas», p. 185. Apart from the magician protagonist, the tale bears no resemblance to that of Don Yllán.

19 Nos. 20, 221, 24, 30, 32, 35, 41, 46, and 47. LIDA DE MALKIEL, «Tres notas», p. 158.

20 Of the three motifs that coincide uniquely in the Don Yllán/Egyptian sorcerer tale, only one (D2012: King in Bath enchanted so that minutes seem years) is evident in documented Arabic sources. See Hasan M. El-Shamy, Types of the Folktale in the Arab World: A Demographically Oriented Tale-Type Index (Bloomington, IN 2004) pp. 370-372, no. 0681. However, none of these, including those of Maghrebī provenance, bears significant resemblance to Don Yllán/The Egyptian Sorcerer. For a literary example, see René BASSET, Mille et un contes, récites \& légendes arabes, 3 vols. (Paris 1924-1926) vol. 3, p. 552, no. 337. For respective Moroccan and Tunisian versions, see Mohammed EL-FASI and Emile DERMENGHEM, Contes fasis, recueillis d'après la tradition orale (Paris 1926) p. 47, No. 1 and Arabische Volksmärchen, ed. Jahn SAMJA, trans. Samja JAHN (Berlin $1970)$ p. 204 , no. 24 . The motif D. 2031.5 (Man enchanted so as to believe he is king, emperor, or pope) is totally absent from El-Shamy's index. The several tales he lists under H. 1565 (Test of Gratitude) are all animal fables that, like the King in Bath tales, bear only superficial similarity to way they are novelized in the Don Yllán/Egyptian Sorcerer tale. See El-SHamy, Types, p. 1085. 
We do, however, find an analogue in Ibn Sahula's Mešal Haqadmon $\bar{r}^{21}$ The $M Q$ is an expansive moral-didactic frame tale crafted in rhyming prose and interspersed with poetry in the style of the maqama. ${ }^{22}$ Its narrative framework contains fables and poetry as well as discourses on astrology, medicine, and optics. ${ }^{23}$ Appearing in part 4, «On Humility,» Ibn Sahula's exemplum of the Egyptian Sorcerer is interpolated in a discussion between two fable characters, the Dove and the Crow, as a negative example of one who did not respect the

21 The text is extant in seven manuscripts: A (Milan, Ambrosiana X 112 sup.), G (Jerusalem, Hebrew University, Heb $4^{\circ}$ 6698), L (Sassoon 691; M. Munich, Bayerische Staatsbibliothek, cod. hebr. 107), $\mathrm{O}_{1}$ (Oxford, Bodleian Library, Canonici or. 59), $\mathrm{O}_{2}$ (Oxford, Bodleian Library, Oppenheimer 154), and R (Jerusalem, Israel Museum, 180.51). There are six pre-modern printed editions (listed by Loewe), and a modern edition: Isaac ben Solomon Ibn Sahula, Mešal haqadmonī, ed. Israel ZAMORAH (Tel Aviv 1953). For a complete textual history, see Loewe's introduction to his English verse translation: Ibn Sahula, Meshal, pp. cxi-cxxiii. I cite Loewe's edition of Ibn Sahula's text; the English translations are mine -I believe that a literal translation affords better access to the original. Loewe summarizes the tale in his synopsis of the entire work: Ibn Sahula, Meshal 1, pp. xliii-xliv. For a summary in Hebrew, see Jefim SCHIRMAnN and E. Fleischer, Studies on Hebrew Poetry in Christian Spain and Southern France [Hebrew] (Jerusalem 1997) pp. 360-361. For an edition of the excerpted tale of the Egyptian sorcerer, see Jefim SchirmanN, Hebrew Poetry in Spain and Provence [Hebrew] (Jerusalem - Tev Aviv 1956) vol. 2, pp. 387-400. For a poetic English translation, see Raymond P. SCHEINDLIN, «The Sorcerer», in Rabbinic Fantasies, eds. David STERN and Mark J. MIRSKY (New Haven 1990) pp. 295-311. For a literal English translation, see David WACKS, «Ibn Sahula's Tale of the Egyptian Sorcerer: A Thirteenth Century Don Yllán», eHumanista 4 (2004) pp. 1-12: Available: http://www.spanport.ucsb.edu/projects/ ehumanista/volumes/volume_04/Articles/Wacks.pdf. A Spanish translation has yet to appear in print. It is noteworthy that this Hebrew version has completely eluded scholars of the Conde Lucanor; Schirmann, however, has pointed out its similarity to the Don Yllán Tale: Schirmann, Hebrew, vol. 2, p. 387, n. 63.

22 See Rina Drory, «The maqama», in The Literature of Al-Andalus, eds. María Rosa MENOCAL, Michael Sells and Raymond P. SCHEIndLin (Cambridge 2000) pp. 190-210, Carl BRockelmann and Charles Pellat, «Makama», in The Encyclopedia of Islam CD-Rom Edition v. 1.0 (= EI) (Leiden 1999), and Abraham Meir HABERMANN, «Maqama», in EJ.

23 See HABERMANN, «Sahula». 
learning of his elder. ${ }^{24}$ Ibn Sahula's didactic focus differs from that of Juan Manuel, but the plotlines of the two versions are parallel. Ibn Sahula's version can be summarized as follows:

A young man from Jerusalem travels to Egypt in search of a teacher of the magic arts. There he meets an old man who agrees to take him in and teach him what he seeks. The young man, however, asks for a tutor his own age who may explain the older sorcerer's lessons to him in simpler terms. The sorcerer, apprised of the young man's insolence, vows to demonstrate his powers to the upstart, ${ }^{25}$ yet agrees to find the young man the desired tutor. He then invites the young man to dine and lodge at his house, promising that they will commence their studies the following morning. After drinking the sorcerer's wine, the young man retires to his room. On his way there, he sees a well in the middle of a field, into which he falls. After spending the night searching around a cave at the bottom of the well, he finds a door that leads him outside to a city. In the city of Kezib, ${ }^{26}$ his facility with rhetoric and poetry earns him a high position at court; eventually he weds the king's daughter and accedes to the throne himself. One day, while relaxing in his palace courtyard, he watches his son fall into a well. He jumps in to save his son, but instead sees the Egyptian sorcerer, who reveals the illusion and upbraids the young man for his arrogance. The latter is contrite,

\footnotetext{
24 Before telling the story, the Crow notes that one must demand respect by judiciously demonstrating one's powers. See Ibn Sahula, Meshal 2, pp. 451-553.

25 «He made a vow to himself: "before I go into a tent or a room, before I go up to the bed of my divan, I will show him my wisdom and my knowledge. I will demonstrate to him my power, intellect, and understanding.'» Ibn Sahula, Meshal, p. 197.

26 One might translate this as 'Liarstown,' or perhaps 'Fibbsville.' The deceptive go-between in Judah ibn Shabbetay's Minhat Yehuda, Śne Hanašim (Offering of בוב Yehudah, Misogynist) is similarly named Kozbi, from the same Hebrew root (cognate with Arabic كانب كذب, 'liar'). See Judah ben Isaac Ibn Shabbetai, 'Minhat Yehuda', 'Ezrat ha-našim' we-'En mišpat', ed. Matti Huss, 2 vols. (Jerusalem 1991) vol. 1. See also Tova RosEN, «On Tongues Being Bound and Let Loose: Women in Medieval Hebrew Literature», Prooftexts: A Journal of Jewish Literary History 8 (1988) pp. 67-87: p. 167, and Michelle M. HAMILTON, Transformation and Desire: The Go-between in Medieval Iberian Literature, Ph. D. Dissertation (University of California at Berkeley 2001) pp. 211-254.
} 
horrified at his error, and agrees to be a good student who will respect the learning of the sorcerer; for his part, the magician agrees to take on the reformed young man as a student in the magic arts.

Although there is considerable divergence in the two authors' versions, the plot parallels are striking, and nearly every aspect of Juan Manuel's innovation praised by critics is evident in Ibn Sahula's version. ${ }^{27}$ The plots of the two tales are so similar that it is nearly impossible that they could have evolved separately, and the fact that they were both written in Castile within a span of 60 years strongly suggests a local source. Overall, the two versions coincide most significantly in the plot structure (i.e., tale type) and in specific narrative motifs. The first noticeable similarity between the two tales is the desire, on the part of an ambitious young man, to enter a recognized center of magic studies. Ibn Sahula's protagonist is forced to travel to Egypt, because magic is forbidden in his homeland of Zion. In Juan Manuel's version, the Deán of Santiago travels to Toledo, a well-known center for studies in necromancy, in order to learn from Don Yllán, a known expert on such subjects.

Next, the sorcerer agrees to instruct the disciple, but insists on offering him hospitality prior to their first class meeting: ${ }^{28} \mathrm{Ibn}$ Sahula's sorcerer invites the young man to 'pour out [his] needs, 29 whereupon the two proceed to eat and drink and spend the evening in conversation. ${ }^{30}$ Similarly, Don Yllán insists on providing the Deán with hospitality before beginning their studies. The Deán's accomodations are ideal: «muy buenas posadas, e todo lo que ovo mester». ${ }^{31}$

\footnotetext{
27 Serés notes Juan Manuel's skillful combination of the motifs of the test of promises and illusory time, as well as the use of suspense in not revealing the temporal illusion to the audience until the tale's end. See Juan Manuel, El Conde Lucanor, pp. 52-54. Devoto praises Juan Manuel's «fina arquitectura psicológica.» DEVOTO, Introducción, p. 384.

28 For exemplum 11 as an example of hospitality, see FLORY, Conde, p. 91.

29 Ibn Sahula, Meshal 2, p. 455, 1. 380.

${ }^{30}$ Ibn Sahula, Meshal 2, p. 455, 1. 383.

31 Juan Manuel, Obras 2, p. 99, 1. 32.
} 
Before actual study, both sorcerers take the measure of their potential disciples, then to reveal their doubts to the reader. In his discussion with the young man, Ibn Sahula's sorcerer notices that his would-be pupil 'did not trust in the [sorcerer's] wisdom, nor did he respect his intelligence.' ${ }^{32}$ Don Yllán goes even further by directly voicing his fear that after the Deán gets what he is seeking, he will not keep his promise. ${ }^{33}$

The sorcerer's temporal illusion is triggered when food and drink are served; in Ibn Sahula's version, the master offers his student a cup of wine, which the young man drinks. Soon, the young man's 'thoughts became different,' and he begins to hallucinate. ${ }^{34}$ In Juan Manuel's tale, Don Yllán orders the preparation of the famous perdices, asking the serving girl to wait for his order before putting them on the fire. ${ }^{35}$ In both cases, it is the hospitality offered by the sorcerer that frames the illusion designed to lay bare the poor intentions of the disciple.

In both cases the illusion takes place underground. Ibn Sahula's protagonist falls down a dry well that becomes a cave leading to a (false) world, ${ }^{36}$ whereas the Deán follows Don Yllán down to his study, so far underground, «que passaba el rio de Tajo por çima dellos.» ${ }^{37}$

Once under the spell of the elder sorcerers, both disciples hallucinate their personal and professional progress. Ibn Sahula's young man travels to the city, where he receives accolades by the leader of

32 Ibn Sahula, Meshal 2, p. 455, 1. 383.

33 «Reçelaua que de que el oviesse aprendido del aquello que el queria saber, que non le faria tanto bien commo el le prometia.» Juan Manuel, Obras 2, p. 99, 11. 40-42.

${ }^{34}$ Ibn Sahula, Meshal 2, p. 461, 1. 60.

35 Juan Manuel, Obras 2, p. 99, 11. 51-54.

36 Ibn Sahula, Meshal 2, p. 461-463.

37 Juan Manuel, Obras 2, p. 99, 1. 58 In reference to Juan Manuel's version, Barcia notes: «el descenso a la cámara subteránea es una manera de aislarse de la realidad inmediata y penetrar en un nuevo ámbito; es el ingreso al mundo de la magia (...).»Pedro BARCiA, «Don Illán y el Deán de Santiago: Para el comentario del ejemplo XI de El Conde Lucanor", in Historia y crítica de la literatura española: Edad Media, ed. Alan DEYERMOND (Barcelona 1980), vol. 1 pp. 202-206: p. 205. 
the scribes' guild, ${ }^{38}$ makes his debut at court, ${ }^{39}$ enters the service of the King, ${ }^{40}$ marries the King's daughter, ${ }^{41}$ builds himself a palace, ${ }^{42}$ and fathers a son. ${ }^{43}$ In Juan Manuel's version, the Deán of Santiago is promoted to Archbishop of Santiago, ${ }^{44}$ then Bishop of Toulouse, ${ }^{45}$ then Cardinal in Rome, ${ }^{46}$ and finally Pope. ${ }^{47}$ This quick success leads both students to moral weakness. Ibn Sahula's young man forgets his birthplace and Jewish origins, ${ }^{48}$ reveling in material comfort and a high social position in a foreign land. ${ }^{49}$ His obsession with his foreign wife's beauty causes him to forget his status and provenance. As for the Deán, he repeatedly reneges on his promise to promote Don Yllán's son, and even threatens the sorcerer with imprisonment when Don Yllán continues to press his claim. Thus, both disciples reveal themselves as arrogant and hypocritical.

Once the disciple proves himself unworthy, the sorcerer calls attention to the mechanism that originally triggered the illusion, at which point the protagonist realizes that all his accomplishments have been illusory. He has been tested and has failed. Ibn Sahula's sorcerer points out to the young man the following: «Here in my hand is the cup from which you drank, the wine of stumbling that you drained. This I have done to make you understand my wisdom and tell of it, so that you might see and understand.» ${ }^{50}$ In Don Juan

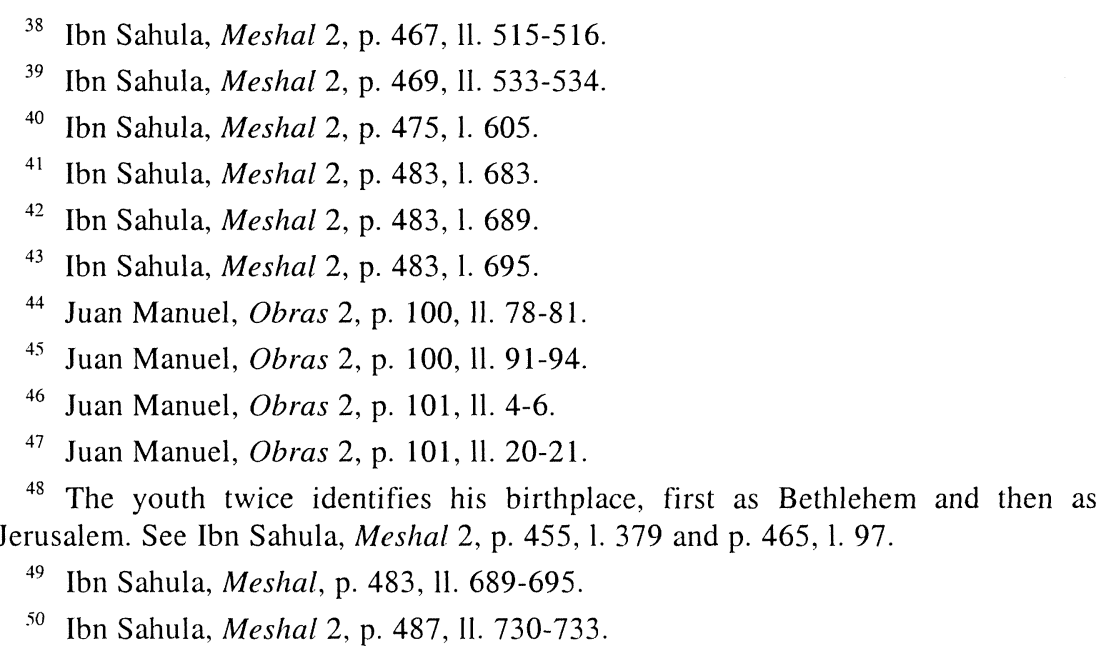


Manuel's version, the Pope sends Don Yllán away from Rome without any rations for the journey, whereupon the sorcerer reminds the Deán of the perdices he had ordered prepared on the night of their first meeting. Don Yllán then calls for the serving girl to put the birds on the fire, the illusion is undone, and the two are back in Toledo on the night they first met. ${ }^{51}$

There are several parallels between the two versions, among them the magician's test of his disciple, the underground setting, the graduated rise of the disciple, and the embarrassing dénouement. Much of the combination of motifs and the psychological dimension praised by critics of Juan Manuel's eleventh exemplum are present in Ibn Sahula's text, a work completed roughly 60 years before El Conde Lucanor. These similarities, combined with the absence of any analogous tales in Hebrew, Arabic, or Latin tradition, favor a common, local, oral origin in a Castilian folktale. This suggests that a Jewish author writing in Hebrew in the late thirteenth century, and a Christian author writing in Castilian in the mid-fourteenth shared -to a significant extent- a common popular linguistic and cultural heritage.

Despite this common origin, the two versions demonstrate very different literary values. Thus, each recasting of the tale amounts to a fully independent literary version that differs significantly from the other in didactic orientation, narrative discourse, and attitudes toward magic and magicians. These are reflective of the very different social, religious, and educational backgrounds of Ibn Sahula and Don Juan Manuel, and are characteristic of the diversity of literary production in medieval Castile.

Some of the differences in the two versions can be attributed to the overall didactic purpose of the works in which they appear. How did the authors themselves conceive the didactic function of their respective works? We are fortunate in that both authors were quite explicit on the matter, and addressed such in the prologues of their respective works. Ibn Sahula states that his aim in writing the $M Q$ was to claim some of the prestige of Arab didactic literature, philosophy

51 Juan Manuel, Obras 2, p. 102, 11. 39-40. 
and science for a Hebrew readership. ${ }^{52}$ His project to raise the prestige of Hebrew as a secular literary and scientific language parallels Alfonso X's contemporary efforts to establish Castilian as a learned language. ${ }^{53} \mathrm{Ibn}$ Sahula is attempting to balance the secular and religious values of a minority culture, the intellectual institutions of which were being threatened by a creeping secularism, especially at the highest levels of society. ${ }^{54}$ Ibn Sahula feared that Hebrew was in danger of being displaced as the primary language of learning in the Jewish communities of Spain: via his scholarship and creativity he sought to restore its prestige, penning a virtuoso work of secular learning framed by Jewish values. He declares that «Jews have disgraced their role as chosen people through their neglect of the Hebrew language, and have become dependent on Greek and Arabic for learning.» ${ }^{55}$ Thus, the main thrust of Ibn Sahula's stated didactic

52 Ibn Sahula, Meshal, pp. xxi-xxiii.

53 See Francisco MÁrquez VillanUeva, El concepto cultural alfonsí (Madrid 1994) p. 35. It is interesting to note that the Alfonsine translation project, undertaken to promote Castilian as a language of secular learning, was initiated as the ArabicHebrew translation movement was concluding. The Jewish translators who worked under Alfonso's direction belonged to the generation following that of the Jewish translators (such as the Ibn Tibbon family and Judah al-Harizin) who had worked to promote Hebrew as a language of secular learning. From a socio-cultural approach, the two are simply phases in a single movement, a concept deserving further investigation. On Arabic-Hebrew translation in medieval Iberia and Southern France, see Abraham Solomon HALKIN, «Tibbon, Ibn», in EJ, Abraham Solomon HALKIN, «Translation», in EJ, Jonathan DECTER, «Subduing Hagar: The Hebraization of Arabic Writing in the Thirteenth Century,» (Unpublished essay, 2004), Abraham DAVID, «Judah ben Eleazar», in EJ, and Aharon MIRSKY, «Hebrew Language», in EJ: especially the section «Original Prose Works and Translations».

${ }^{54}$ Ibn Sahula, Meshal 1, p. xxii.

55 Ibn Sahula, Meshal 1, p. 5. Al-Harīzì similarly inveighed against such intellectual assimilation in the introduction to the Tahkemoni: Judah al-Harizī, Tahkemoni, ed. Yisrael TOPOROVSKY and Yisrael ZAMORAH (Tel Aviv 1952) pp. 810. See also the English translation: Judah al-Harizīi, The Book of Tahkemoni: Jewish Tales From Medieval Spain, trans. David Simha SEgAL (London 2001) pp. 11-17. The debate over the superiority of Arabic vs. Hebrew letters ('arabiyya / 'ibräniyya) had already been ongoing for more than two hundred years when Ibn Sahula wrote. See, for example, S. M. STERN, «Rationalists and Kabalists in Medieval Allegory», Journal of Judaic Studies 6 (1952) pp. 73-86, Abraham S. HALKIN, «The medieval Jewish attitude towards Hebrew», in Biblical and Other 
purpose is to remind Jews to stay true to their intellectual and religious origins, as well as to reinforce the practice of a scientific and philosophical literary culture in Hebrew. ${ }^{56}$ It is within this framework that we must consider Ibn Sahula's tale. In fact, the story can be read as a metaphor for Spanish-Jewish intellectuals in Ibn Sahula's time. The fictive audience of the author's prologue are ambitious and talented young Jewish scholars who forsake their linguistic homeland in search of foreign learning. So, too, does the protagonist of Ibn Sahula's tale leaves Jerusalem in order to pursue the study of forbidden magic arts in Egypt.

Writing some years later, as someone at the upper echelons of the politically dominant Christian society, Juan Manuel was bound to have a very different approach in his novelization of the tale of the sorcerer and his disciple. His stated didactic concern is primarily

Studies, ed. Alexander Altmann (Cambridge 1963) pp. 233-248, Rina Drory, «Literary Contacts and where to find them: On Arabic literary models in medieval Jewish literature», Poetics Today 14 (1993) p. 277-302, Id., «Words Beautifully Put: Hebrew vs. Arabic in Tenth-Century Jewish Literature», in Genizah research after 90 years, The case for Judeo-Arabic, eds. Joseph BLAU and Stefan REIF (Cambridge 1992) pp. 53-66, and Nehemiah Allony, «The Reaction of Moses Ibn Ezra to 'arabīyya», Bulletin of the Institute of Jewish Studies 3 (1975) pp. 19-40.

56 Hebrew occupied a peculiar space in its linguistic practice; it had never been a natural, colloquial language among the Jews of al-Andalus or Spain, but rather was confined to the synagogue and the literary academy. In al-Andalus, scientific and philosophical texts by Jewish authors were typically drafted in Arabic. Beginning in the late twelfth century, Jews living in Christian kingdoms began to translate Arabiclanguage learning into Hebrew, for the benefit of European Jewry with no knowledge of Arabic. The same translators involved in this effort, such as Judah alHarīzi $\overline{\mathbf{1}}$, then began to compose original works of secular literature in Hebrew. For a general overview of Jewish language use in medieval Iberia, see Consuelo LóPEZMORILLAS, «Language», in The Literature of Al-Andalus, eds. María Rosa MENOCAL, Raymond P. SCHEINDLIN and Michael SELLS (Cambridge 2000) pp. 33-59: pp. 41-46, Elaine Miller, Jewish Multiglossia: Hebrew, Arabic and Castilian in Medieval Spain (Newark, DE 2000), and Shelomo MORAG, «The Jewish Communities of Spain and the Living Traditions of the Hebrew Language», in Moreshet Sepharad: The Sephardi Legacy, ed. Haim BEINART (Jerusalem 1992) vol. 1, $103-$ 114. On al-Harizzī, see SCHIRMAnN, Hebrew, vol. 2, pp. 97-103, SCHIRMAnN and FLEISCHER, Toldot, pp. 145-221, and the introduction of Del Valle Rodríguez to his Spanish translation of Tahkemonī: Judah al-Harīzī, Las asambleas de los sabios (Tahkemoni), trans. Carlos DEL VALLE Rodríguez (Murcia 1986). 
spiritual. Whereas Ibn Sahula wrote for the Jewish community, arguing for the preservation of Hebrew as a language of intellectual inquiry, Juan Manuel wrote for his fellow Christian noblemen, instructing them on how to preserve their reputations and estates. ${ }^{57}$ Like Ibn Sahula, he is writing for a specific audience, but with a different purpose. While Ibn Sahula preaches faithfulness to the Jewish religion, language, and intellectual tradition, Juan Manuel «is preaching a straightforward doctrine of self-interest.» ${ }^{58}$ His choice of language is not made to preserve Spanish from extinction, but rather to promote its use as a language of secular literature in order to reach an audience of nobles not educated in Latin. ${ }^{59}$ Both are proponents of a preferred language for reasons that reflect on their individual circumstances.

In both cases, the author's didactic purpose (and target audience) inevitably affects authorial and/or narrative voice, discourse, and style. Concordant with his focus on the cultivation of Hebrew as a high register literary and scientific language, Ibn Sahula's rhyming prose is representative of the style of medieval prose writers working in Arabic and Hebrew: prolix, intentionally ornate, and even obscure, writing couched in high rhetoric, perhaps equivalent to Góngora's poetic style. ${ }^{60}$ The rhyming prose he chooses is a virtuoso genre: its technical exigencies are meant to highlight the author's poetic and rhetorical talents. Yet for a Hebrew author of the thirteenth century, his prose style is conventional. Ibn Sahula's innovation lies in his

\footnotetext{
57 «deseando que los omnes fiziessen en este mundo tales obras que les fuessen aprovechosas de las onras e de las faziendas e de sus estados.» Juan Manuel, Obras 2, p. 23.

58 Ian Richard MACPHERSON, «Dios y el mundo - The Didacticism of El Conde Lucanor», Romance Philology 24 (1970) pp. 26-38: p. 27.

${ }_{59}$ In the general prologue to his collected works, Don Juan Manuel writes the following: «Pero Dios sabe que lo fizo por entençion que se aprouechassen de lo que el diria las gentes que non fuessen muy letrados nin muy sabidores. Et por ende fizo todos los sus libros en romançe, et esto es sennal çierto que los fizo para los legos et de non muy grand saber commo lo el es.» Juan Manuel, Obras 2, pp. 23-24, 11. 30-34.

${ }^{60}$ On style in the Hebrew maqaimat, see Naoya KATSUMATA, «The Style of the Maqama: Arabic, Persian, Hebrew, Syriac», Arabic and Middle Eastern Literatures 5 (2002) pp. 117-137: pp. 124-125.
} 
attempt to cultivate a wide range of secular subjects of inquiry in Hebrew. He is not an innovator in style nor in narrative technique. Rather, his writing is characteristic of previous frametale literature in Arabic, Hebrew, and Castilian. ${ }^{61}$

In contrast, Juan Manuel is, indeed, a pioneer in his prose style, particularly in his use of colloquial language and quotidian detail more characteristic of a popular storyteller or preacher than a courtly or religious orator (as in the maqamät). Above all, critics have emphasized his use of popular, oral-discursive language and personal voice. Barcia cites his «léxico (...) vasto,» «vocabulario popular,» and lack of rhetorical ornamentation. ${ }^{62}$ Macpherson adds that Juan Manuel's prose is «idiosyncratic» for a medieval writer since it reflects the author's personal experience. ${ }^{63}$ The oral features of his style are owed to Juan Manuel's penchant for having chivalric and exemplary narratives read to him; instead of imitating features of texts that he personally read, he incorporates his experience of performances of oral narrative or readings of written texts. ${ }^{64}$ Thus, in these texts we see two very different types of discourse; Ibn Sahula employs a highly ornate and technical literary style pitched to a minority audience of elite Jewish intellectuals. ${ }^{65}$ Juan Manuel controls a more popular and oral discursive style, targeted to less well-educated but politically dominant and individually powerful Christian nobles.

${ }^{61}$ i.e., Ibn al-Muqaffa"s Kalila wa-Dimna, the anonymous Sindbad al-Hakim (Book of the Seven Sages) and their respective Hebrew and Castilian translations. See J. P. Guillaume, «Sindbad al-Hakim», in EI, and Brockelmann and Pellat, «Makama».

62 Pedro Luis BARCIA, Análisis de El Conde Lucanor (Buenos Aires 1968) pp. 43 and 45 .

63 Ian Richard MACPHERSON, «Don Juan Manuel: The Literary Process», Studies in Philology 70 (1973) pp. 1-18: p. 3.

${ }^{64}$ Macpherson, «Don Juan», p. 9. On orality in the Conde Lucanor, see also E. Michael GERLI, «Textualidad y autoridad: hacia una teoría de los orígenes de la escritura señorial (el caso de El libro del conde Lucanor)», in Propuestas teóricometodológicas para el estudio de la literatura hispánica medieval, ed. Lillian vON DER WALDE MOHENo (Mexico City 2003) pp. 335-349.

${ }_{65}$ See Ibn Sahula, Meshal 1, p. Ixv. 
The difference in didactic purpose between the two authors is seen most clearly in the figure of the sorcerer. ${ }^{66}$ The practice of the magic arts (i.e., necromancy, divination, and alchemy) was regarded, variously, by medieval Christian and Jewish religious authorities. Whereas no theologian or Rabbi seems to have advocated its practice without caveats, the range of opinions in rabbinic but overall tends toward prohibition. ${ }^{67}$ Necromancy in particular, depending as it does on the summoning of demons, was suspect, often associated in Christian sources with Islam, Judaism, and heresy. ${ }^{68}$ As a result, magic was widely prohibited by both Church and secular authorities, the former being concerned with the sin of the practice of magic, the latter with the resulting harm caused by magicians to fellow subjects. ${ }^{69}$ In Jewish sources, it was generally discouraged, but certain varieties seem to have been tolerated by rabbinic authorities. ${ }^{70}$

\footnotetext{
${ }^{66}$ On magic in medieval Spanish literature, see Jennifer M. CORRY, Perceptions of Magic in Spanish Medieval Literature (Bethlehem, Penn. 2005); Samuel WAXMAN, «Chapters on Magic in Spanish Literature», Revue Hispanique 38 (1916) pp. 325-463. On magic in fifteenth-century Castile and León, see Fernando ÁLVAREZ LÓPEZ, Arte mágica y hechicería medieval (Valladolid 2000).

${ }^{67}$ The practice of magic was strictly prohibited in the Talmud. However, during the Middle Ages there is ample reference to magical texts and practice in Hebrew sources. Curiously, both rabbinic and medieval sources distinguish between magicians (whose powers are physical) and illusionists (who simply perform sleight of hand or alter perception). See Giuseppe VELTRI, «The Figure of the Magician in Rabbinical Literature», Jerusalem Studies in Arabic and Islam 26 (2002) pp. 187204: pp. 198 and 202-203. Nevertheless, magic continued to be a secondary concern to Rabbis and Jewish thinkers. See Joseph DAN, «Magic», in EJ. Certain forms of practical kabbalah, and especially talismanic magic for curative purposes, were cautiously condoned by rabbis, and seemed to have been practiced by certain kabbalists in Provence, Catalonia, and Castile. See Gershom SCHOLEM, Kabbalah (New York 1974) pp. 182-183 and Sara KLEIN-BraSLavy, «The Concept of Magic in R. Solomon ben Abraham Adret (Rashba) and R. Nissim Gerondi (Ran)», in Encuentros and Desencuentros: Spanish Jewish Cultural Interaction Throughout History, eds. Carlos Carrete Parrondo, Marcelo Dascal, Francisco MárquezVillanueva and Angel SÁEnZ-Badillos (Tel Aviv 2000) pp. 105-129.

${ }^{68}$ See Karen Jolly, Catharina RAUdvere and Edward PETERS, Witchcraft and Magic in Europe (Philadelphia 2002) p. 21.

69 See Richard KIECKHEFER, Magic in the Middle Ages (Cambridge 1989) pp. 176-187, and Edward PETERS, The Magician, The Witch, and the Law (Philadelphia 1978) pp. 85-109.

70 Joshua Trachtenberg, Jewish Magic and Superstition (New York 1970) pp. 19-22.
} 
Ibn Sahula is not openly critical of his sorcerer character. As an Egyptian, and presumably a non-Jew, the sorcerer is not subject to Jewish prohibitions on sorcery. ${ }^{71} \mathrm{He}$ represents the young man's seduction by foreign secular values:

for magic was forbidden to the chosen people, to the dwellers of Jerusalem and to the man of Judea. But the young man saw how the desire touched his heart, and how his search would prove impossible in the land of the $t s v \bar{l}^{72}$

Therefore, it is the student, and not the sorcerer himself, who is morally suspect. As a Jew, the young man should know better than to seek out the study of magic. His moral failings are evident both in his actions as well as in the language Ibn Sahula uses to characterize him. A close inspection of Ibn Sahula's language reveals a sustained anti-magic commentary. He often chooses language that alludes to passages used in the Old Testament to portray poor judgment and transgressive actions. ${ }^{73}$ The result is a powerful

71 The portrayal of the magician as non-Jew and outsider has its origin in the Hebrew Bible. See Stephen D. RICKS, «The Magician as Outsider: The Evidence of the Hebrew Bible», in New Perspectives on Ancient Judaism: Society and Literature in Analysis, ed. Paul V. M. Flesher (New York 1990) vol. 5, pp. 125-134.

72 Ibn Sahula, Meshal 2, p. 453, 11. 368-371. i.e., 'the land of beauty'. The word $t s v \bar{\imath}$ can mean either 'stag' or 'beauty, excellence,' and refers here to the land of Palestine.

73 For example, when he first arrives in Egypt, the young man announces to the sorcerer his intentions: «now I have come to seek fulfillment of my wants from every magician, astrologer, and Chaldean» (lekol hartom we'asaf wekasday). Ibn Sahula, Meshal, p. 457, 11. 14-15. The emphasis is mine, indicating a verbatim quotation from Daniel 2:10. In this verse, Nebuchadnezzar assembles his magicians, astrologers, and Chaldeans [i.e., soothsayers] to command them to recount and interpret a disturbing dream he has had, threatening to kill them if he cannot. When they reply that they cannot, Daniel receives a vision from God and is able to fulfill Nebuchadnezzar's request. Ibn Sahula's reference to this particular scene at this moment in his own narrative is an ironic reminder that true knowledge is not to be gained from magicians, but rather from God himself. Once enchanted, the young man hallucinates having built a palace and is relaxing in his courtyard, watching his son «hopping around on a reed staff.»Ibn Sahula, Meshal 2, p. 487, 11. 719-720. Here, 'reed staff,' (miš' 'net haqane) -as opposed to one made from wood- is a flimsy, unreliable staff that is said to split, piercing the hand of one who leans on it (2 Kings 18:21 and Isaiah 36:6). Already in Ezekiel (29:6), it is used metaphorically for something unreliable or to describe a person who foolishly misplaces his trust. The idea is that the child's staff, like everything else in the man's hallucination, appears sound but is shoddy, and that the child, representing the man's earthly but 
intertextuality that imbues Ibn Sahula's characterizations with biblical authority.

Ibn Sahula's audience perceived a text in terms of biblical reference. Since the language available to medieval Hebrew writers was almost entirely derived from Biblical texts (often verbatim), every phrase resonates with the language of the Tanakh (Hebrew Bible). For example, when the young man first comes under the effect of the sorcerer's spell, he falls into a well. Unable to find his way out, his night of suffering is described with the same language used to describe the remorse Joseph's brothers felt after selling him into slavery. ${ }^{74}$ The reference is ironic. Like Joseph, the young man is cast into a pit; unlike Joseph, he is cast there on account of his own foolishness. When he finally finds his way out, his relief upon exiting the pit into a lush garden is that of a «foolish man become wise,» a reference to Job 11:12: «a foolish man will become wise when a wild ass' colt is born a man.» The irony is apparent. Finally, he comes upon a town where he marvels at two towers «painted in red,» ${ }^{75}$ an allusion to Ezekiel's extended metaphor of Judea and Samaria as the harlot sisters Oholah and Oholibah, the former of whom becomes so taken with the images of the Chaldean men «painted in red» on the wall that she lies with them. ${ }^{76}$ This reference equates the young man's pursuit of foreign magic with prostituting one's self to the

illusory accomplishment, rests on a flimsy foundation, one relying on magic and not on religious practice.

74 Literally, «he saw the suffering of his soul (sarat nafso),» Ibn Sahula, Meshal 2 , p. $463,1.66$. The allusion is to Genesis $42: 21$, in which Joseph's brothers express their remorse for having abandoned him in the pit: «We are very guilty concerning our brother, in that we saw the distress of his soul, when he besought us, and we would not hear; therefore is this distresss come upon us.» All English translations of biblical citations are from Jewish Publication Society, The Holy Scriptures (Philadelphia 1955).

75 Ibn Sahula, Meshal 2, p. 463, 1. 79.

76 «And she increased her harlotries; for she saw men portrayed upon the wall, the images of Chaldeans portrayed with vermillion, girded with girdles upon their loins, with pendant turbans upon their heads, all of them captains to look upon, the likenesses of the sons of Babylon, even of Chaldea, the land of their nativity» (Ezekiel $23: 14-16)$ 
enemy; furthermore, it reinforces Ibn Sahula's exhortations against lusting after foreign learning. Throughout the tale, much of the language describing the young man's predicament similarly alludes to biblical descriptions of the suffering of the transgressor. Since Ibn Sahula's target audience would be able to identify most of the biblical allusions, there is a strong, implicit moralizing element to his tale that is not apparent in a literal reading. Ibn Sahula's condemnation of the young man's pursuit of the magic arts, here representative of Jewish acculturation in and assimilation to the secular world, is expressed in terms of biblical intertextuality.

Like Ibn Sahula, Juan Manuel does not seem to condemn sorcery per se. Don Yllán's necromancy is simply his chosen profession, not a testimony of his sin or moral corruption. On the contrary, it is the cleric whose gratitude is in question, and the fact that the target of the Deán's arrogance and hypocrisy is an innocent necromancer only heightens the tale's irony. Given the Church's condemnation of magic and its practitioners, it is curious that Juan Manuel, an author purporting to be concerned with his audience's salvation, chooses a sorcerer to play moral straight man to his transgressive Deán of Santiago. Don Yllán is portrayed simply as an hospitable necromancer, whose profession is called into question only by the hypocritical Deán, who is so enchanted that he believes he is the Pope. ${ }^{77}$ The didactic focus is not on Don Yllán's theological transgression as sorcerer, but on the Deán's ethical transgression as egoist and hypocrite. The question of heresy does not figure into the didactic calculus of the exemplum. This bears out the idea that Juan Manuel is more concerned with worldly self-preservation than with salvation; were the latter the case, the necromancer would surely be cast as morally corrupt, irrespective of the Deán's own ethical failing or heresy (practice of necromancy).

77 When Don Yllán presses the newly appointed 'Pope' to fulfill his promise, the latter threatens throw the sorcerer in prison, reminding him that he is a known heretic and sorcerer, and therefore vulnerable: «que era ereje et encantador, que bien sabia que non avia otra vida nin otro offiçio en Toledo, do el moraba, sinon biuir por aquella arte de nigromançia.» Juan Manuel, Obras 2, p. 101, 11. 32-34. 
What, then, can we conclude regarding the relationship between these two versions, so similar structurally, but so divergent stylistically and didactically? Given the total absence of analogues for the tale in written or oral sources in Latin, Romance, Arabic, and Hebrew, it is most likely that both authors novelized a folktale circulating orally in Castile during the thirteenth and fourteenth centuries. This tale would have combined motifs from other sources, such as those reflected in the exempla collections and in Arabic sources, but first appeared as a distinct tale type in Castile during this time, where it was heard and novelized first by Ibn Sahula and then by Don Juan Manuel.

Ibn Sahula and Juan Manuel were both Castilian writers whose didactic orientation, choice of literary language, and narrative discourse reflected their educational upbringing and life experiences. Despite differences in religion and station, their shared experience was not negligible: both lived in Castile, moved in elite circles in which Jews and Christians freely intermingled, and both grew up speaking Castilian as their native tongue. ${ }^{78}$ Accordingly, it should

\footnotetext{
78 Loewe seems to regard it as a given that Ibn Sahula's mother tongue was Arabic. See Ibn Sahula, Meshal 1, p. lx. He does not attempt (or does not see it necessary) to substantiate this claim. Nonetheless, he gives as list of «Possible Hispanisms» in Ibn Sahula's Hebrew. See Ibn Sahula, Meshal 1, p. cviii. If Ibn Sahula's Hebrew (a learned language) shows the influence of Spanish (a primarily vernacular language in the process of becoming a learned one), it would stand to reason that Ibn Sahula was a Spanish speaker, probably a native. Nonetheless, we find it highly improbable that any Jew or Christian raised in thirteenth-century Guadalajara would have been a native speaker of Arabic and not Castilian. It is entirely likely that Ibn Sahula was able to read and write classical Arabic. However, such ability does not in any way indicate that he was a native speaker of Andalusī vernacular Arabic, nor does it diminish the likelihood of him having been a native speaker of Castilian. Even before the Reconquest, there are several documented examples of vernacular Romance language use among the Jewish community of alAndalus. Stern, for example, maintains that it «might almost be taken for granted» that Andalusī Jews «made everyday use of the Mozarabic [Romance] of its Muslim and Christian neighbors.» See S. M. STERn, Hispano-Arabic Strophic Poetry: Studies, ed. L. P. HARVEY (Oxford, Eng. 1974) p. 151. Stern's statement is borne out by authorities such as Shelomo ibn Gabirol, who lamented the sorry state of Hebrew letters amongst the Jews of Zaragoza, noting that «half of them talk the language of the Christians ('adomit), and the other half Arabic (bilšon bene kedar).» See
} 
not be surprising that they coincided in their choice of narrative material, for the two authors drew from a common vernacular culture. What should be surprising is that this Hebrew antecedent to the Don Yllán tale has gone unnoticed by Hispanists until now.

\section{RESUMEN}

En este artículo, el autor compara el exemplo de Don Yllán y el Deán de Santiago -n. ${ }^{\circ} 11$ en el Conde Lucanor (ca. 1335) de Don Juan Manuel- con una versión anterior en la obra hebrea, Mešal Haqadmonī (ca. 1285) de otro autor castellano, Isaac ibn Sahula. Un análisis cuidadoso del estilo narrativo y retórico de ambas versiones revela que las dos comparten una fuente común en la tradición oral castellana. La aparición del cuento en un texto hebreo anterior de Castilla (la única versión conocida en cualquier otra lengua) cuestiona la originalidad literaria del más famoso exemplo de Don Juan Manuel, y sugiere un intercambio productivo entre una tradición oral común castellana y tradiciones literarias hebreas y castellanas coexistentes.

Palabras Clave: Don Juan Manuel, Conde Lucanor, Isaac ibn Sahula, Meshal Haqadmoni.

\section{SUMMARY}

In this article the author compares the exemplo of Don Yllán and the Deán de Santiago -no. 11 in Don Juan Manuel's Conde Lucanor (ca. 1335)- with an earlier Hebrew analogue found in the Hebrew Mešal Haqadmonī (ca. 1285) of fellow Castilian author Isaac ibn Sahula. A thorough analysis of the rhetorical and narrative style of both versions reveals that the two tales shared a common source in Castilian oral tradition. The appearance of the tale in an earlier Hebrew text from Castile (the only other known version in any language) calls into question the originality of Don Juan Manuel's most famous exemplo, suggesting a productive interplay between a common oral tradition in Castilian and coexisting literary traditions in Hebrew and Castilian.

KEYwords: Don Juan Manuel, Conde Lucanor, Isaac ibn Sahula, Meshal Haqadmoni.

Shelomo Ibn Gabirol, The Poetry of Shelomo ben Yehudah Ibn Gabirol [Hebrew], ed. Hayyim Nahman BIALIK and Yehoshua Hana RAWNITZKI, 5 vols. (Tel Aviv 1927) vol. 5, p. 173, 11. 15-16. In the following century, Maimonides describes a literary gathering where poems are recited in Hebrew, Arabic, and Romance. Mišna 'im peruš Moše ben Maimon, ed. and trans. Y. QAFIH, Neziqin 'avot (Jerusalem 1964) vol. 4, p. 419, cited in James T. MONROE, «Maimonides on the Mozarabic Lyric», La corónica 17 (1988-89) pp. 18-32: p. 20. 